\title{
DINAMIKA KOMUNIKASI ORGANISASI MUHAMMADIYAH DIY DAN PENCALONAN SENATOR DPD RI DALAM TINJAUAN TEORI KEPRIBADIAN KELOMPOK RAYMOND CATTELL
}

\author{
Dani Fadillah \\ Universitas Ahmad Dahlan, Jl Semaki, Umbul harjo, Kotamadya Yogyakarta \\ dani.fadillah@comm.uad.ac.id
}

\begin{abstract}
This Paper aims to find out how the dynamics of Muhammadiyah's requirements in the Daerah Istimewa Yogyakarta during the 2019 election period on the candidate for the nomination of the senator who will serve as the board of Regional representative of the Republic of Indonesia. In conducting this research the author collects data in the form of polls and interviews with representatives of Muhammadiyah cadre of Daerah Istimewa Yogyakarta, then the data that authors acquire in the surgical use of personality theory that was triggered by Raymond Cattell as the surgical knife of the analysis. The results of this study show that Muhammadiyah still has to increase the political awareness of cadres to be more given the political situation. Even though the culture of an excellent organic cadre has established in the natural cadres of Muhammadiyah, Daerah Istimewa Yogyakarta, the culture needs to be maintained and enhanced to harmony in Muhammadiyah.
\end{abstract}

Keywords : Muhammadiyah, Communication Organization, Group Syntality Theory of Raymond Cattell

\begin{abstract}
Abstrak
Paper ini disusun untuk mengetahui bagaimana dinamika yang terjadi dalam tubuh persyarikatan Muhammadiyah di Daerah Istimewa Yogyakarta selama masa-masa pemilihan umum 2019 dalam masalah pencalonan senator yang akan menduduki kursi Dewan Perwakilan Daerah Republik Indonesia. Dalam melakukan penelitian ini penulis mengumpulkan data berupa angket dan wawancara dengan perwakilan kader Muhammadiyah Daerah istimewa Yogyakarta, kemudian data yang penulis peroleh dibedah menggunakan teori kepribadian yang dicetuskan oleh Raymond Cattel sebagai pisau bedah analisisnya. Hasil dari penelitian ini menunjukkan bahwa Muhammadiyah masih harus meningkatkan kesadaran politik kader-kadernya agar lebih jeli dalam melihat situasi yang bersifat politis. Meski begitu telah terbangun budaya organsiasi yang sangat baik dalam diri kader-kader organik Muhammadiyah daerah Istimewa Yogyakarta, budaya itu perlu dipertahankan dan ditingkatkan agar keharmonisan dalam tubuh Muhammadiyah senantaisa terjaga dengan baik.
\end{abstract}

Kata Kunci : Muhammadiyah, Komunikasi Organisasi, Teori kepribadian kelompok Raymond Catell

\section{Pendahuluan}

Dalam kehidupan bernegara

partisipasi masyarakat dan aspirasi masyarakat tidak bisa dipisahkan, dalam menjalankan roda pemerintahan pemerintah tidak bisa menjalankannya 
seorang diri, diperlukan yang namanya parrsisipasi dari masyarakat agar setiap keputsan yang diambil oleh pemeritah tidak salah sasaran dengan harapan tujuan dari berdirinya dapat dicapai dengan hasil yang semaksimal mungkin. Dan bagaiamana mungkin masyarakat dapat berpartisipasi jika masyarakat tidak mampu untuk menyalurkan aspirasiya. Oleh karena itulah tertampungnya aspirasi masyarakat sangat menentukan bagaimana nasib sebuah bangsa dalam menjalani hariharinya dalam wadah bernama negara.

Dahulu Dewan Perwakilan Rakyat / Majelis Pewakilan Rakyat dipercaya sebagai sarana mengumpulkan aspirasi masyarakat, setiap anggota dewan yang lolos ke senayan dipercaya membawa aspirasi masyarakat dari daerah pemilihannya masing-masing. Akan tetapi seiring berkembangnya budaya politik tanah air, para anggota dewan dari partai politik dinilai cenderung lebih mengedepankan kepentingan partai dan bukannya kepentingan daerah pemilihannya. Hingga akhirnya pada tahun 2001 dengan sedikit penyesuaian dalam Undang-Undang Dasar 1945 dibentuklah sebuah badan baru bernama Dewan perwakilan Daerah yang bertujuan untuk memastikan adanya keseimbangan antar daerah di Indonesia dan memastikan sampainya aspirasi dari masyarakat yang ada di daerah ke tingkat pemerintahan pusat (DPD RI 2019).

Agar tujuan dari dibentuknya Dewan Perwakilan daerah tercapai maka para senator yang diusulkan untuk maju ke senayan adalah mereka yang merupakan representasi dari perwakilan kelompok masyarakat di suatu daerah, bukan dari perwakilan partai politik. Dikhawatirkan jika yang sampai masuk menjadi senator Dewan Perwakilan daerah adalah perwakilan dari partai politik maka hal sebelumnya terjadi di institusi Dewan Perwakilan Rakyat bisa terulang di institusi Dewan Perwakilan Daerah, dimana sang anggota dewan lebih fokus dalam menyuarakan kepentingan partai dari pada kepentingan wilayah pemilihannya (Fabian Januarius Kuwado 2018).

Melihat adanya peluang untuk turut berpartisipasi dalam ranah konstitusi melalui perwakilan daerah yang seharusnya diisi oleh kelompok non partai politik, maka Pimpinan Wilayah Muhammadiyah Daerah Istimewa Yogyakarta melalui Musyawarah Pimpinan Khusus memutuskan untuk mengirimkan salah satu kader terbaiknya guna duduk sebagai senaor Dewan Perwakilan Daerah Republik Indonesia di 
daerah pemilihan daerah istimewa Yogyakarta ini, karena ada kader Yogyakarta dengan mengusung nama Muhammadiyah yang juga merupakan Afnan Hadikusumo (Redaksi 2018). anggota partai politik untuk maju sebagai

Keputusan mengutus nama salah calon senator Dewan Perwakilan daerah. satu kaderr terbaiknya ini diambil oleh Muhammadiyah dengan salah satu pertimbangannya adalah Muhammadiyah bukan organisasi politik namun tidak boleh anti politik, maka adanya peluang untuk bisa berpartisipasi mengawal aspirasi masyarakat dari daerah melalui Dewan Perwakilan Daerah yang memang seharusnya diisi oleh perwakilan masyarakat adalah langkah yang tepat karena Muhammadiyah sendiri merupakan organisasi kemasyarakatan berbasis agama (Mediamu 2018).

Kebijakan dari Pimpinan Wilayah Muhammadiyah daerah Istimewa ini disambut dengan baik oleh kader-kader persyarikatan Muhammadiyah di Daerah Istimewa Yogyakarta, bahkan organisasi otonom milik Muhammadiyah pun memberikan dukungan bulat terhadap keputusan ini, para kader Muhammadiyah bergabung dalam tim pemenangan calon senator dari Muhammadiyah ini mulai dari tingkat wilayah, daerah, cabang hingga ranting (Ivan Aditya 2019).

Sempat ada dinamika dalam proses pemunculan nama oleh Pimpinan Wilayah Muhammadiyah Daerah Istimewa Muncul nama lain ini yang ditenggarai ingin mengambil suara kader Muhammadiyah di Daerah Istimewa Yogyakarta, akan tetapi suara suara kaderkader organik Muhammadiyah sudah bulat bahwa hanya ada satu nama yang akan disusung oleh Muhammadiyah, maka seluruh kader harus bersatu meloloskan nama itu dan tidak memberi tempat bagi nama lain yang ingin menggerogoti suara Muhammadiyah (Ainun Najib 2019). Oleh karena berbagai dinamika yang telah terjadi itu lah maka penulis ingin melakukan kajian secara mendalam terkait Muhammadiyah daerah Istimewaa Yogyakarta dan Pencalonan Senator DPD RI dalam tinjauan kepribadian kelompok yang dicetuskan oleh Raymond Cattell.

Teori kepribadian melompok menitikberatkan pada interaksi internal yang ada dalam suatu keompok dengan berbagai dinamika kepribadian yang menyelimuti para anggota kelompoknya. Secera lebih sederhana dapat dipahami bahwa perbedaan individu yang ada dalam suatu kelompok mulai dari usia, latar belakang, hingga karakteristik yang berbeda-beda secara otomatis akan 
menjadi semacam kesatuan yang akan menjadi kepribadian dan wajah kelompok, keberadaan mereka yang berbeda dalam sebuah kelompok yang sama akan terpadu menjadi satu atas nama kelompok.

Raymond pun menerangkan bahwa tugas tiap anggota kelompok untuk kelompoknya ada dua, yaitu melaksanakan tugas kelompok baik yang memang dibebankan khusus padanya atau pun tugas tersebut merupakan mimpi besar kelompok yangharus turut dipikulnya demi tercapainya tujuan kelompok. Dan tugas yang berikutnya adalah memastikan agar anggota kelompok yang lain terpelihara perilaku dan moralnya hingga tidak ada satu pun anggota kelompuk yang membahayakan keberlangsungan kelompok dari dalam.

Raymond Catell menyimpulkan bahwa hubungan antar individu para anggota kelompok ditentukan oleh berbagai struktur variabel kelompok, dan yang paling menentukan adalah bagaimana struktur-struktur yang ada itu bersinergi Perilaku manusia yang bergabung dalam kelompok akan bergerak dengan seketika ketika ada hal-hal yang dianggap membahayakan kelompok baik yang berasal dari pihak-pihak dari dalam mau pun dari luar kelompok, hal itu menjadi kemampuan yang terjadi secara alami dari dalam diri manusia, dalam bahasa lain Raymond Cattell menyebutnya dengan cognitive abilities (Flanagan and Dixon 2014).

Dan konsep sinergi ini masih menurut cattel dapat tersusun dari dua macam kegiatan yang usahakan oleh para pengurus kelompok, yaitu maintenance energy dan effective energy. Yang pertama adalah adanya kegiatan langsung yang diarahkan pada upaya umtuk pemeliharaan kelompok guna memastikan kohesi kelompok dan harmoni kelompok. Sedangkan upaya yang kedua artinya adanya adanya kegiatan yang diarahkan langsung pada tujuan kelompok.

Oleh karena itu lah berdasarkan fenomena yang terjadi terkait dinamika yang dialami oleh Muhammadiyah dalam memperjuangkan utusannya agar lolos menjadi senator Dewan Perwakilan Daerah maka penulis merasa tertarik untuk melakukan kajian secara mendalam terkait fenomena tersebut mnggunakan pendekatan teori kepribadian kelompok milik Raymond Casstell.

\section{Metode Penelitian}

Penelitian ini mnggunakan pendekatan deskriptif kualitatif. Penulias dalam melakukan penelitian ini melakkan wawancara dengan perwakilan kader- 
kader Muhammadiyah yang tergabung dalam Pemuda Muhammadiyah, Ikatan Mahasiswa Muhammadiyah, Tapak Suci, Ikatan pelajar Muhammadiyah, dan sisanya hanya bekerja di Amal Usaham Milik Muhammadiyah. Selain itu juga melakukan wawancara dengan para pengurus Muhammadiyah yang masuk menjadi tim sukses Afnan Hadikususmo serta kader Muhammadiyah yang menjatuhkan dukungannya pada kandidat selain Afnan Hadikusumo selaku satusatunya wakil dari persyarikatan Muhamamdiyah. Angket juga turut penulis sebar kan pada simpatisan Muhammadiyah yang berada di daerah Istimewa Yogyakarta.

Selain mengambil data dari para kader Muhammadiyah secara langsung, berbagai informasi yang beredar di media massa pun turut penulis ambil untuk dijasikan data pelengkap dalam penelitian ini. Semua data yangg telah penulis dapatkan baik itu data primer, sekunder hingga tersier lantas peneliti olah sedemikian rupa menggunakan pisau bedah teori kepribadian kelompok milik Raymond Casstell lantas merumuskan hasil penelitian yang diperoleh.

\section{Hasil Penelitian dan Pembahasan}

Ada pun temuan dan pembahasan yang didapatkan oleh penulis saat melakukan penelitian ini sebagai berikut:

Pertama; Berdasarkan kusisioner yang penulis diperoleh data bahwa $96 \%$ kader persyarikatan Muhammadiya di Daerah istimewa Yogyakarta telah mengetahui bahwa di Dewan Perwakilan daerah Republik Indonesia adalah orangorang perwakilan kelompok masyarakat non partai politik, dan hanya ada empat persen yang masih belum mengetahuinya. Itu lah kenapa ketika ketika Peryarikatan Muhammadiyah Daerah Istimewa Yogyakarta melakukan sosialisasi terhadap salah satu nama calon senator atas nama Afnan Hadiksuumo masih ada beberapa kader persyarikatan Muhammadiyah yang bertanya-tanya kenapa Muhammadiyah seperti melakukan kampanye politik. Meski sudah ada upaya dari kader-kader Muhammadiyah lainnya untuk menekankan bahwa Dewan perwakilan daerah memang harus diisi oleh kelompok masyarakat non partai politik namun empat persen respon ini mayoritas masih merasa sulit untuk memahami.

Akan tetapi meski bertanya-tanya seperti itu, dalam keseharisnnya mereka juga tidak bisa menyebutkan siapa nama 
calon yang akan mereka pilih jika bukan

Afnan hadiksusumo sebagai nama calon senator Dewan Perwakilan Daerah darah Istimewa Yogyakarta .yang senantiasa disosialisasikan oleh Muhammadiyah. Ketika ditanya kenapa tidak memilih nama lain jika mereka menganggap bahwa Muhammadiyah melakukan politik praktis layaknya partai politik, rata-rata menjawan bahwa hasil Musyawarah Pimpinan Khusus harus dihormati oleh warga peryarikatan.

Kedua; Berdasarkan kuisioner yang dibagikan kader persyarikatan Muhammadiyah Daerah Istimewa Yogyakarta ketika ditanyakan apakan memiliki nama lain yang disusung jika seandainya nama Afnan Hadikusumo belum dimunculkan maka 40\% diantaranya menjawab ada. Nama-nama alternatif itu muncul berdasarkan data yang berhasil penulis peroleh disebabkan beberapa alasan: Afnan Hadikusumo dianggap sudah tidak lagi muda, maka sudah sepantasnya digantikan oleh mereka yang berusia lebih muda mengingat Muhammadiyah di Daerah Istimewa Yigykakarta dinilai memiliki banyak sto pimpina muda berkualitas maka akan sangat baik jika tempat tersbut diisi oleh mereka sebagai bentuk regenerasi
Selanjutnya adalah Afnan Hadiksumo sudah dua kali dicalonkan oleh Pimpinan Wilayah Muhammadiyah Daerah istimewa Yogyakarta sebagai senator Dewan Perwakilan Daerah yaitu pada pemilihan umum tahun 2009 dan 2014, dan selama dua periode itu pula Afnan hadikusumo sennatiasa terpilih meski tidak ada dasar hukum yang menyatakan bahwa seseorang hanya bisa terpilih sebanyak dua kali untuk mendapatkan posisi di Dewan Perwakilan Daerah, namun tetap saja bagi beberapa kader ada perasaan yang mengganjal, kenapa masih ingin kembali menjabat untuk yang ketiga kalinya.

Alasan berikutnya kenapa mereka memunculka nama selain Afnan Hadikusumo adalah karena mereka tidak merasa kenal dan dekat dengan sosok yang diusung oleh Pimpinan Wilayah Muhammadiyah Daerah Istimewa Yogyakarta ini, bahkan ada yang mengaku bahwa dirinya sama sekali belum pernah bertemu dengan Afnan hadiksumo meski dalam 2009 dan 2014 memilihnya untuk maju sebagai senator.

Ketiga alasan itu lah kenapa berdasatkan data yang penulis peroleh hanya ada $70 \%$ kader Muhammadiyah darah Istimewa Yogyakarta yang menyambut gembira munculnya nama 
Afnan Hadikusumo dari hasil Musyawarah Wilayah Pimpinan Khusus Pimpinan Wilayah Muhammadiyah Daerah Istimewa Yogyakarta, sisanya menyatakan tidak gembira dan yang lain masih raguragu.

Untuk menghadapi kedua temuan itu yang berpotensi membahayakan rencana Muhammadiyah Daerah istimewa Yogyakarta untuk mengirmkan wakilnya menjadi senator Dewan perwakilan Daerah adalah dengan memasifkan komunikasi organisasi yang bersifat formal dan kultural. Strategi yang bersifat formal adalah dengan memberikan instruksi resmi tetulis pada seluruh organisasi otonom dan Amal Usaha milik Muhammadiyah yang ada di Daetah istimewa Yogyakarta agar turut aktif dalam mempromosikan Afnan Hadikusumo dalam menyongsong pemilihan umum 2019.

Bentuk aktifitas nyata yang terjadi dari kader-kader organik Muhamamdiyah adalah mereka menyediakan diri untuk bergabung menjadi tim sukses kandidat yang dicalonkan oleh Muhammadiyah baik namanya berada dalam daftar tim sukses resmi yang diserahkan pada Komisi Pemilihan Umum mau pun sebagai tim sukses bayangan yang namanya tidak tercatat. Serta beberapa kader organik menarik diri dan mengundurkan diri dari keoengurusan sebuah partai politik yang berupaya menyusupkan salah satu nama kader partainya sebagai calon Dewan Perwakilan Daerah, dan titenggarai sosok ini akan menggerogoti suara Muhammadiyah dengan pencalonan dirinya. Proses penarikan diri dan pengunduran diri besar-besaran kader Muhammadiyah Daerah istimewa Yogyakarta dari partai politik ini disebut dengan gerakan kosongkan gerbong partai. Meski bukan organisasi politik, namun kader-kader Muhammadiyah, khsusnya yang berada di Daerah Istimewa Yogyakarta, banyak yang memiliki kepiawaian dalam berpolitik dan kepiawaian dalam mengambil sikap terhadap keputusan yang berbau politis (Fadillah 2017).

Sedangkan Amal Usaha Muhammadiyah untuk mendukung suksesnya kader Muhammadiyah lolos ke senayan sebagai senator Dewan Perwakilan Daerah adalah dengan melakukan sosialisaasi secara masif terhadap karyawan, siswa/mahasiswa, keluarha siswa/mahasiswa, dan masyarakat sekitar tempat Amal usaha Muhammadiyah itu berdomisili bahwa ada kader Muhammadiyah yang akan mewakili aspirasi masyarakat Daerah 
Istimewa Yogyakarta. Dukunga sosialisasi luar ruang pun dilakukan oleh seluruh Amal Usaha Muhammadiyah, mulai dari menyediakan lahannya untuk dibentangkan banner bergambar wajah Afnan hadiksuumo, menempelkan wajah beserta nama dan nomor urut Afnan Hadikusumo di mobil-mobil dinas milik instansi Muhammadiyah hingga ada pula yang dan sebagainya.

Pendekatan secara kultural pun juga digereliyakan oleh kader-kader yang telah sepakat untuk meloloskan kader persyarikatan Muhammadiyah ke senayan melalui jalur Dewan perwakilan Daerah, forum-forum silaturahmi antar kader ditingkatkan baik dalam forum silaturahmi yang berbalut disukusi hingga obrolanobrolan serius tapi sanatai di warungwarung kopi yang berserakan di tiiap sudut kota Yogyakarta dan sekitarnya. Tujuannya sama: menguatkan lapisan yang sedikit terkelupas, kader-kader yang masih ragu untuk mendukung Afnan hadiksuusmo atau merasa kecewa karena nama Afnan Hadikusumo kembali muncul sebagai kandidat yang diajukan oleh Pimpinan Wilayah Muhammadiyah Daerah Istimewa Yogyakarta menjadi yakin yang mantap untuk mendukung dan memilih Afnan hadukusumo di hari pemungutan suara.
Dalam logika kepribadian kelompok Raymond Cattell temuan-temuan tersebut dapat dilihat bahwa meski adanya rasa yang mengganjal dalam diri seorang kader Muhammadiyah terkait hasil keputusan organisasi, namun rasa kesetiaan dan perasaan ingin turut mengawal arah dan tujuan organsiasi masih terus ada. Loyalitas kader terbagun dengan matang hingga samai berani untuk mengundurkan dari kepengurusan partai politik yang sebenarnya lebih masuk dalam zona "lahan basah".

Ketika muncul indikasi bahwa ada rekannya sesama kader organisasi yang berpotensi untuk terlempar dari jalur yang seharusnya, naluri cognitive abilities anggota oragnisasi langsung bereaksi. Kader-kader organik yang masih berada dalam jalur dan arahan organisasi langsung mengambil tidakan yang tersistematis dan masif agar jangan sampai ada rekannya sesama anggota persyarikatan yang akan mengambat tujuan dari organisasi. Dalam bahasa Raymond Cattell sebagaimana yang telah disinggung di atas adalah bagaiaman setiap anggota kelompok "mengawal moral anggota kelompok lainnya", karena memang adalah sebuah bentuk degradasi moral berorganisasi jika ada anggota kelompok yang kemudian melenceng dan menghambat laju 
organsiasi, terlebih jika organsiasi tersbut sedang mengupayakan hal yang baik duntuk kepentingan masyarakat luas.

Peranan maintenance energy banyak dimainkan oleh kader-kader Muhammadiyah Daerah istimewa Yogyakarta dalam berbagai gerakan non formal seprti menyelesaikan berbagai urusan dengan cara yang santai seperti melanjutkan diksusinya di warung kopi atau lapangan futsal, sehingga dalam kondisi yang tenang dan nyaman pesan menjadi lebih mudah untuk dituangkan dan diterima oleh para pihak yang sedang menjalankan proses komunikasi. Dengan berbagai cara non formal terkesan kultural itu pula keharmonisan antar anggota organisasi Muhammadiyah tetap terjaga.

Sedangkan effective energy banyak dilakukan oleh institusiMuhammadiyah dan Amal Usaha yang dimilikinya. Arahan dari pimpinan organisasi pada karyawan dan tenaga kerja lainnya serta berbagai macam potensi sumber daya manusia yang ada didalam dan disekitar posisi geografis Amal Usaha Muhamamdiyah yang hendak memenagkan Afnan Hadiksumo menjadi jalur yang efektif. Kader-kader Muhammadiyah yang bekerja di Amal usaha Muhammadiyah itu secara otomatis akan mengikuti arahan jelas dan tegas dari pimpinan institusi, sedangkan pihak yang hanya bekerja di Amal Usaha Muhamadiyah sedangkan dia bukan kader Muhammadiyaha kan terkena terpaan pesan dari rekan-rekan kerja disekitarnya yang merupakan kader Muhammadiyah, sudah mendapat arahan dari pimpinan dan semua rekan kerja yang lain mendukung arahan tersebut, maka hal itu akan mepengaruhi pillihan politiknya (Fadillah 2015).

\section{Simpulan}

Masih banyak jumlah kader Muhammadiyah yang tidak mengetahui peran dari Dewan Perwakilan daerah republik Indonesia dan siapa saja yanglayak untuk duduk disana, sehingga di banyak wilayah masih terjadi kecolongan dengan tersusupinya kader partai politik menjadi senator Dewan Perwakilan Daerah yang lolos ke senayan (Fachrudin n.d.). Oleh karena itu pendidikan politik kader masih harus perlu dilakukan dan ditingkatkan, jangan sampai sebagai sebuah organsiasi kemasyarakatan yang tua dan sangat besar Muhammadiyah tidak mampu mewakafkan salah satu kader terbaiknya untuk mengawal suara rakyat di jalur konstitusi yang memang disediakan khsusu untuk kalangan non partai politik.

SemuaAmal Usaha Muhammadiyah memiliki metode perkaderan yang telah 
tersruktur untuk semua karyawannya (Ulfah, Fajri, and Fadillah 2017). Maka materi terkait kesadaran politik Muhammadiyah sepertinya harus ditingkatkan untuk menghindari kemungkinan masih adanya kader Muhammadiyah yang bersifat apatis dan tidak peduli terhadap politik. Selama melakukan peneltian terlihat bahwa kaderkader organik Muhammadiyah lebih menyukai pertemuan yang bersifat kultural, obrolan berbobot di warung kopi lebih disukai dari pada forum formal yang kaku dan tegang, oleh karena itu cara yang bersifat kekeluargaan ini sangat penting untuk dipertahankan. Kekuatan menyampaikan pesan secara langsung dari mulut ke mulut memang masih belum kehilangan sihirnya hingga hari ini .

Kemampuan literasi media kaderkader Muhammadiyah juga perlu ditingkatkan agar ada kepiawaian dalam mebaca tanda-tanda dari berbagai informasi yang bertebaran di era post modern saat ini, agar terbuka wawasannya bawa jangan sampai bersifat apolitis meski Muhammadiyah bukan organisais politik. Karena kiprah konstitusi Muhammadiyah sangat diperlukan dalam mengawal bangsa ini kedepannya (Fadillah 2014).

Internet dan dunia sibber yang terkandung di dalamnya memiliki kemampuan untuk meningkatkan partsisipasi politik masyarakat dan meningkatkan gairah politik warga negara (Uspal Jandevi 2019), sudah selayaknya pula tim media Muhammadiyah mengisi portal dan akun media sosial nya dengan pesan-pesan pendidikan politik tersebut, agar tidak ada lagi kader yang bahkan tidak mengetahui apa perbedaan tugas dewan Perwakilan Rakyat dan Dewan Perwakilan Daerah. Tidak sedikiti kisah sukses meningkatnya partisipasi politik umat karena peranan internet (Ulfah and Barry 2019), tim media Muhamamdiyah hanya perlu mempelajarinya dan memolesnya agar lebih lembut, tidak sekasar media partisan politik lainnya (Lotan 2019).

\section{Daftar Pustaka}

Ainun Najib. 2019. "Ortom Muhammadiyah Bertekad Menangkan M Afnan Hadikusumo.” SindoNews.Com. Retrieved (https://jateng.sindonews.com/read/3 921/1/ortom-muhammadiyahbertekad-menangkan-m-afnanhadikusumo-1555175041).

DPD RI. 2019. “Latar Belakang.” Dewan Perwakilan Daerah Republik Indonesia. Retrieved (http://www.dpd.go.id/halaman392_latar-belakang).

Fabian Januarius Kuwado. 2018. "Bukan 
Rahasia Lagi Kalau DPD Dikuasai

Partai Politik." Kompas.Com.

Retrieved

(https://nasional.kompas.com/read/2

018/07/28/15470891/bukan-rahasialagi-kalau-dpd-dikuasai-partai-

politik).

Fachrudin, Fachri. n.d. "Parpol Diminta

Tak Iming-Imingi Anggota DPD

Agar Jadi Kader Parpol Diminta Tak

Iming-Imingi Anggota DPD Agar

Jadi Kader."

Fadillah, Dani. 2014. "Strategi

Komunikasi Pembentukan Budaya

Organisasi." Humanika 14(1).

Fadillah, Dani. 2015. "Model Komunikasi

'WOM' Sebagai Strategi Pemasaran

Efektif." Humanika 15(1).

Fadillah, Dani. 2017. "Pola Komunikasi

Internal Brajamusti Menjelang

Pilkada Kotamadya Yogyakarta 2017." Informasi 47(1).

Flanagan, Dawn P. and Shauna G. Dixon.

2014. "The Cattell-Horn-Carroll

Theory of Cognitive Abilities." Wiley

Online Library. Retrieved (https://onlinelibrary.wiley.com/doi/f ull/10.1002/9781118660584.ese0431 ) .

Ivan Aditya. 2019. "Muhammadiyah Pastikan Dukung Afnan Hadikusumo." Surat Kabar Harian
Kedaulatan Rakyat. Retrieved (https://krjogja.com/web/news/read/9 6624/Muhammadiyah_Pastikan_Duk ung_Afnan_Hadikusumo).

Lotan, Fitrah Fasyanabilla. 2019. "Making a Positive Internet through Socmed Agawe Guyub." International Journal of Communication and Society 1(1):9-16.

Mediamu. 2018. "Muhammadiyah DIY Usung Afnan Hadikusumo Sebagai Calon DPD RI 2019-2024.” MediaMU. Retrieved (http://www.mediamu.id/2018/07/14/ muhammadiyah-diy-usung-afnanhadikusumo-sebagai-calon-dpd-ri2019-2024/3/).

Redaksi. 2018. "Muhammadiyah Calonkan Afnan Hadikusumo Di DPD RI.” Sang Pencerah. Retrieved (https://sangpencerah.id/2018/04/mu hammadiyah-calonkan-afnanhadikusumo-di-dpd-ri/).

Ulfah, Mariana and Amadou Barry. 2019. "Indonesia Leader Forum, Post-Truth and Political Interests in Social Media and Television." International Journal of Communication and Society 1(1):17-25.

Ulfah, Mariana, Choirul Fajri, and Dani Fadillah. 2017. "Pemahaman Literasi Media Di Lingkungan Pengurus 
Pimpinan Wilayah Aisyiyah Daerah

Istimewa Yogyakarta Periode 20152020." Informasi 47(2).
Uspal Jandevi. 2019. "New Media for Increasing Political Participation in Indonesia." International Journal of Communication and Society 1(1):18. 